\title{
An Early Triassic conodont with periodic growth?
}

\author{
ZHANG SHUNXIN ${ }^{1}$, RICHARD J. ALDRIDGE ${ }^{2}$ \& PHILIP C. J. DONOGHUE ${ }^{2,3}$ \\ ${ }^{1}$ China University of Geosciences, 29 Xueyuan Road, Beijing 100083, China. \\ ${ }^{2}$ Department of Geology, University of Leicester, Leicester LE1 7RH, UK. \\ ${ }^{3}$ Present address: School of Earth Sciences, University of Birmingham, Edgbaston, Birmingham B15 2TT, UK.
}

\begin{abstract}
Elements of a new Triassic conodont genus Parapachycladina, from the Lower Triassic Beisi Formation of western Guangxi Province, China, show a characteristic pattern of lamellar edges in the recessive basal margin. The lamellae are grouped in sets of 8-10, with broad interlamellar spaces between each set. If this apparent periodicity reflects annual cycles, the specimens were not more than four years old when they ceased growing. J. Micropalaeontol. 16(1): 65-72, May 1997.
\end{abstract}

\section{INTRODUCTION}

Lower Triassic conodonts were first described by Müller (1956), and have subsequently become quite well known. One characteristic member of the fauna is the genus Pachycladina, which occurs in shallow-water deposits in Europe, North America and China. Founded by Staesche (1964) as a form genus, with $P$. obliqua Staesche as type species, the multielement nature of Pachycladina was recognized by Sweet (1981) in the Treatise on Invertebrate Paleontology. Sweet (1981, p. W154) regarded the apparatus as seximembrate, with a carminate to palmate $\mathrm{Pa}$ element, digyrate $\mathrm{Pb}, \mathrm{M}$ and $\mathrm{Sb}$ elements, a bipennate $\mathrm{Sc}$ element and an alate Sa element with no posterior process. All the elements are 'hyaline, with thick growth axes in all denticles'; the aboral surface on each has a small basal pit and $a$ broad zone of recessive basal margin, forming a scarlike area on the inner and outer sides of the Pa element but only on the inner side of other elements. In Sweet's (1988) classification, the genus is placed in the family Ellisoniidae of the order Prioniodinida.

Zhang (in Zhang \& Yang, 1991, 1993) reported four species of Pachycladina from western Guangxi, China: $P$. obliqua, $P$. bidentata Wang \& Cao, P. erromera Zhang and P. peculiaris Zhang. The last species departs from the diagnosis of Pachycladina given by Sweet (1981) in having an Sa element with a posterior process, which bears one or two reclined denticles on some specimens. A similar Sa element from the Thaynes Formation of Utah was illustrated as Pachycladina sp. by Solien $(1979$, pl. 1, figs 16, 18). Zhang (in Zhang \& Yang, 1991) therefore revised the diagnosis to include Sa elements with a denticulate or adenticulate posterior process as well as those without a posterior process.

We have restudied specimens of $P$. peculiaris and compared them with those of other species referred to Pachycladina. In addition to the distinctive Sa element, specimens of $P$. peculiaris display surface microstriae and a characteristic structure in the lamellae of the crown, revealed in the recessive basal margin. We use these features to diagnose a new genus, Parapachycladina, and speculate on the growth history recorded by the coronal lamellae.

\section{SYSTEMATIC PALAEONTOLOGY \\ Class Conodonta Pander, 1856 \\ Order Prioniodinida Sweet, 1988 \\ Family Ellisoniidae Clark, 1972 \\ Genus Parapachycladina nov.}

Type species. Pachycladina peculiaris Zhang (in Zhang \& Yang,
1991), sample YT228, Beisi Formation (Lower Triassic), Taiping, Pingguo, Western Guangxi Province, China. Holotype: specimen 59875, China University of Geosciences, Beijing (Zhang, in Zhang and Yang, 1991, pl. 3, figs 7a, 7b).

Diagnosis. Apparatus seximembrate, composed of ramiform elements with intergrading morphology. Pa extensiform digyrate, $\mathrm{Pb}$ extensiform to breviform digyrate, $\mathrm{M}$ breviform digyrate, Sa alate with posterior process, Sb breviform digyrate, slightly asymmetrical, $\mathrm{Sc}$ bipennate. All elements robust, with discrete peglike denticles containing white matter. Aboral surfaces of all elements with small basal pit and broad zone of recessive basal margin. Cusp and denticles of all elements with longitudinal microstriae.

Remarks. The genus is currently monospecific. It differs from Pachycladina in the arched and bowed processes of the $\mathrm{P}$ elements, the posterior process of the Sa element, in the grouping of the lamellae in the recessive basal margin into sets and in the presence of longitudinal surface striations. Surface striations are clearly apparent at a magnification of $300 \times$ on the specimens illustrated as Pachycladina sp. and P. symmetrica Staesche by Solien $(1979, \mathrm{pl} .1$, figs 18, 20) and these are assigned here to Parapachycladina peculiaris. The denticle surfaces of Chinese specimens of $P$. obliqua, $P$. bidentata and $P$. erromera are very smooth, even at magnifications as high as $3000 \times$. These observations suggest that surface microstructure is a valuable character in the reconstruction of the apparatuses of Triassic ellisoniids.

The recognition of Parapachycladina as a separate genus removes the necessity for the revised diagnosis of Pachycladina provided by Zhang (in Zhang \& Yang, 1991).

Parapachycladina peculiaris (Zhang, in Zhang \& Yang, 1991) (Pl. 1, figs 1-4; Pl. 2, figs 1-6; Pl. 3, figs 1-12)

1979 Pachycladina symmetrica Staesche; Solien: 304, pl. 1, figs 17, 20 (Sb element).

1979 Pachycladina sp. Solien: 304, pl. 1, figs 12, 13 (Pa element), figs 16,18 (Sa element).

1990 Pachycladina peculiaris sp. n. Zhang: pl. 2, figs 4 (Pa element), 7 (Sa element).

1991 Pachycladina peculiaris sp. n. Zhang; Zhang \& Yang: 4042, pl. 3, figs 1-12 (all elements).

1993 Pachycladina peculiaris Zhang; Zhang \& Yang: pl. 5, figs 17 (all elements).

Diagnosis. Pa with faint ribs along processes; Sa with denticulate or adenticulate posterior process. 
Zhang et al.

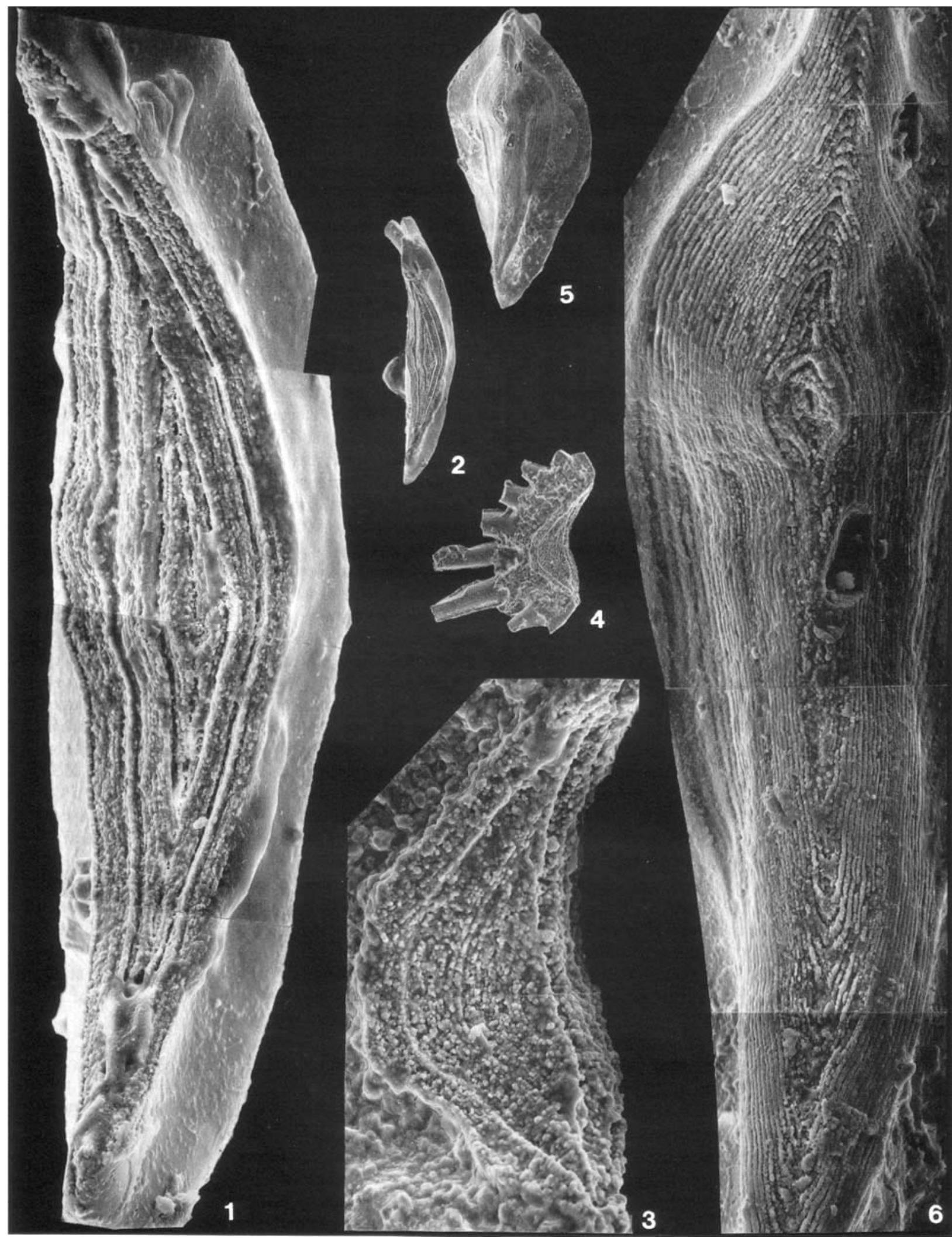

Explanation of Plate 1

Figs 1, 2. Parapachycladina peculiaris (Zhang in Zhang \& Yang, 1991), Pa element, specimen PM X 1900, Beisi Formation, sample YT 228 . Fig. 1. Aboral surface detail, $\times 424$. Fig. 2. Aboral view, $\times 73$. Figs 3, 4. Parapachycladina peculiaris (Zhang in Zhang \& Yang, 1991), Pb element, specimen PM X 1901, Beisi Formation, sample YT 228. Fig. 3. Lateral view of basal margin, $\times 424$. Fig. 4. Lateral view, $\times 73$. Figs 5, 6. Pachycladina obliqua Staesche, 1964, Pa element, specimen PM X 1902, Beisi Formation, sample YT 246. Fig. 5. Aboral view, $\times 73$. Fig. 6. Detail of aboral surface, $\times 424$. 


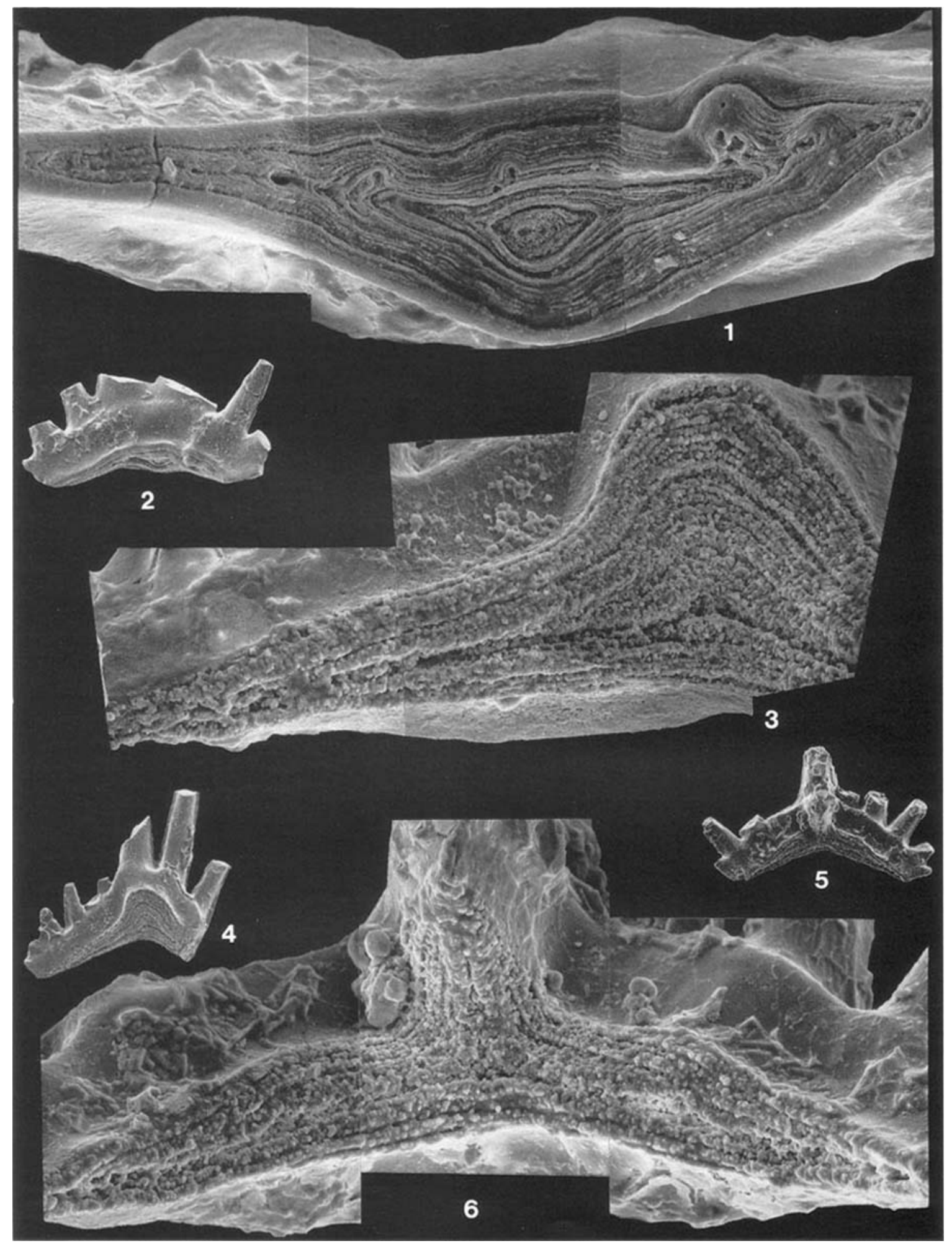

Explanation of Plate 2

Parapachycladina peculiaris (Zhang in Zhang \& Yang, 1991), Beisi Formation, sample YT 228. Fig. 1. Pa element, specimen PM X 1903, detail of aboral surface, $\times 424$. Fig. 2. Pa element, specimen PM X 1903, lateral view, $\times 73$. Fig. 3. M eiement, specimen PM X 1904, posterior view of basal margin, $\times 424$. Fig. 4. M element, specimen PM X 1904, posterior view, $\times 73$. Fig. 5. Sa element, specimen PM X 1905, posterior view $\times 73$. Fig. 6. Sa element, specimen $\mathrm{PM} \times 1905$, posterior view of basal margin, $\times 424$. 

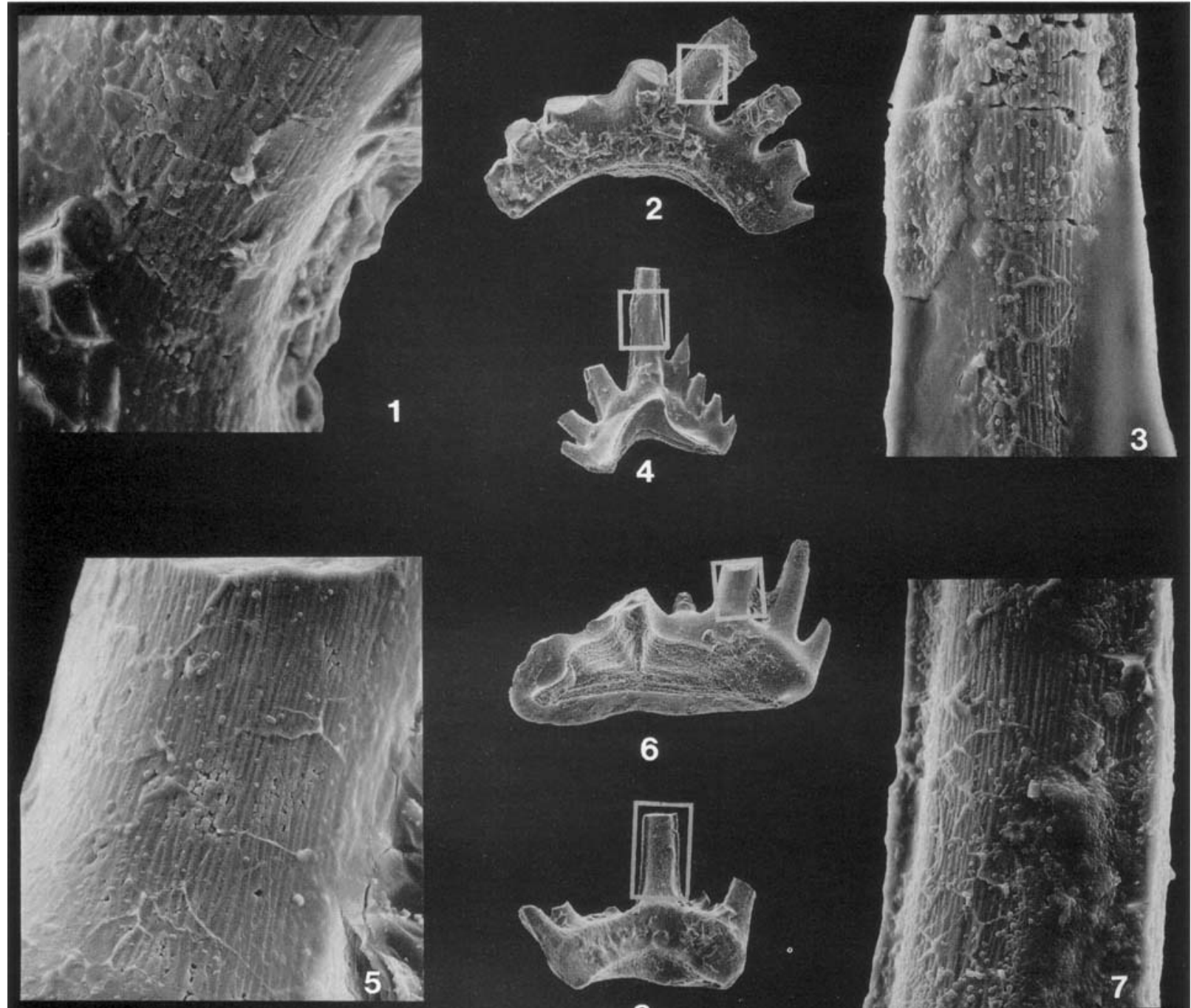

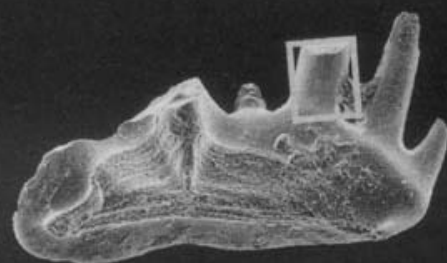

6

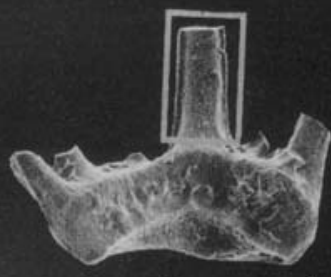

8
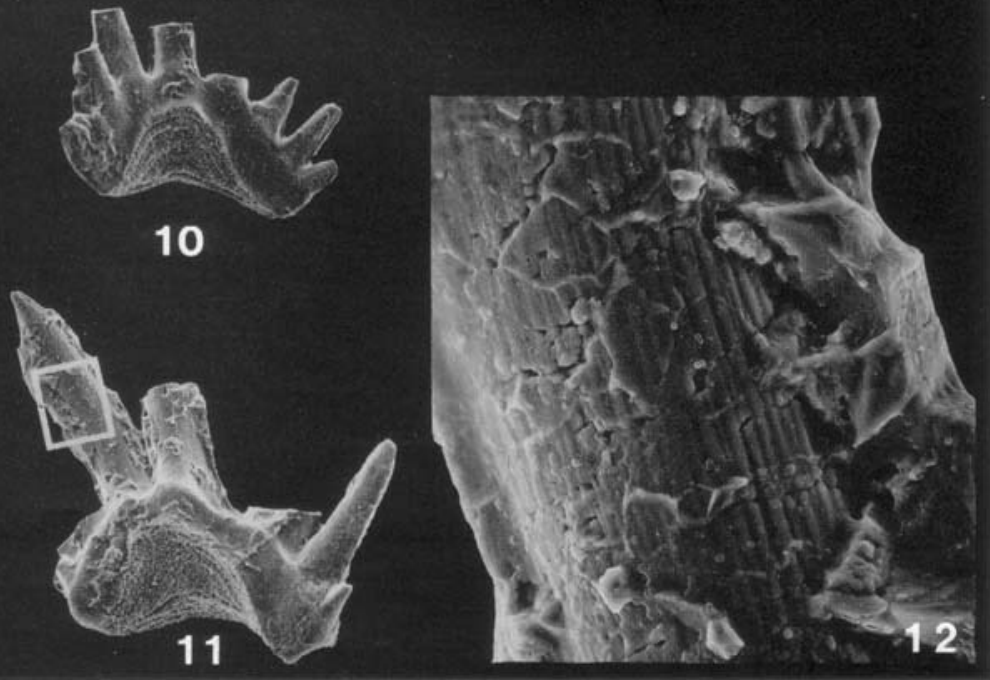

Plate 3 
Material. $\mathrm{Pa}$ element 22, $\mathrm{Pb}$ element $17, \mathrm{M}$ element 26, $\mathrm{Sa}$ element 17, Sb element 19, Sc element 23. From sample YT228, lower part of Beisi Formation, Taiping village, Pingguo County, western Guangxi Province, China; Lower Triassic Pachycladina obliqua-Parachirognathus delicatulus Assemblage Zone (see Zhang, 1990).

Repository of figured specimens. Natural History Museum, London.

Remarks. The elements of $P$. peculiaris were described by Zhang \& Yang (1991). Additional characters are the striae (Pl. 3, figs 1, $3,5,7,12)$, the grouping of lamellae revealed in the recessive basal margins of all elements (Pl. 1, figs 1-4; Pl. 2, figs 1-6; Pl. 3, Figs 9,10$)$ and the presence of white matter in the cores of denticles. Longitudinal microstriae are present on the cusp and all denticles of every element of $P$. peculiaris; only the sharp denticie margins are smooth. The scale $(<0.7 \mu \mathrm{m})$ places them in the fine striation category of Lindström \& Ziegler (1981). The striae are continuous for the entire denticle length, running parallel for considerable distances but also bifurcating and anastomosing, particularly near the base.

\section{CONODONT ELEMENT STRUCTURE}

Conodont elements are characteristically constructed from two basic units, the crown and the underlying basal body. Mineralized basal bodies are, however, unknown in Triassic conodont specimens. The aboral surface of the crown is, therefore, always exposed, and the edges of the coronal lamellae are usually visible on the basal attachment area of the element. In $P$. peculiaris, as in other ellisoniids, the aboral surface of all elements displays a central pit surrounded by a scar-like recessive area, where the edge of each lamella did not extend as far basally as its predecessor. The shape of this recessive area varies with the morphology of the element, but all specimens show a consistent arrangement of the edges of the coronal lamellae. Each visible lamella is separated from its neighbours by an interlamellar space, with the lamellae further grouped into sets by markedly broader intervening spaces. Four such sets are evident in most specimens; except for the outermost, in which the number is variable, each set comprises 8-10 lamellae (Pl. 1, figs 1, 3, Pl. 2, figs 1, 3, 6, Pl. 3, fig. 9).

\section{HARD TISSUE HISTOLOGY}

The crowns of conodont elements are constructed of concentric apatite lamellae, which grew through outward secretion, each successive larnella enveloping much of the exterior surface (see Lindström \& Ziegler, 1981). The arrangement of crystallites in the lamellae and the incremental lines led Sansom et al. (1992) to compare this crown tissue with the enamel of vertebrates.

The specimens of Parapachycladina have been thermally altered to CAI 5 (in excess of $300^{\circ} \mathrm{C}$ ), but transmitted light and scanning electron microscopy of whole elements and of etched thin sections has allowed identification and differentiation of histological tissues. Etched thin sections show elements to be heavily fractured internally, and in most specimens this masks the histological structure. However, the best-preserved specimens clearly display the lamellar structure, reflecting the pattern observed in the recessive-basal margin ( $\mathrm{Pl}$. 4, figs 1-7). The cores of denticles in Parapachycladina also contain 'white matter', a relatively etch-resistant, fine-grained tissue, interpreted by Sansom et al. (1992) as cellular bone (Pl. 4, fig. 3). The blocks of white matter fill the tips of each denticle, flanked by lamellar crown tissue (Pl. 4, figs 3,5). Between the batches of lamellae are blocks of white matter which form the denticle core (Pl. 4, fig. 1). The figured section is cut slightly obliquely to the true axis of the curved cusp, so the true extent of the subsumed denticles represented by blocks of white matter cannot be seen.

\section{INTERPRETING THE GROWTH PATTERN}

Episodic growth of conodont crowns is evident from their intrinsic lamellar structure, but the lamellar pattern in Parapachycladina suggests that a broader periodicity may also be represented. Episodic structures separating groups of lamellae have previously been recognized in thin sections of conodont elements by Müller \& Nogami (1971, p. 27, text fig. 17), who attributed them to resorption. In their examples, the zones of postulated resorption do not coincide with the zones of accretion, thereby producing internal truncations in the lamellar structure. No such truncations are apparent in our specimens of Parapachycladina. Müller \& Nogami's figures also show differing numbers of lamellae between each postulated resorption layer. Their interpretation of these features as due to resorption may or may not be correct, but in any event they do not appear to be comparable with the structures we describe here.

There is now a substantial body of evidence indicating that the systematic position of the conodonts lies among the primitive vertebrates, and that the elements functioned as teeth (Briggs, 1992; Sansom et al., 1992; Aldridge et al., 1993; Janvier, 1995; Purnell, 1995; Gabbott et al., 1995). It is therefore appropriate to consider the occurrence of episodic patterns in the skeletal structures of other vertebrate groups. For example, periodic growth of skeletal elements in fishes has long been known, and the resulting structures are commonly used to determine fish ages (e.g. Hartley, 1947; Panella, 1971; Tesch, 1971). Fish scales, in particular, may show wide rings at the beginning of a season's growth, becoming narrower and slightly irregular towards the end of the season, with a well-marked boundary before the resumption of the next season's rapid growth. In many fish these ring-line boundaries are formed at the end of the spawning season (Hartley, 1947, p. 8).

\section{Explanation of Plate 3}

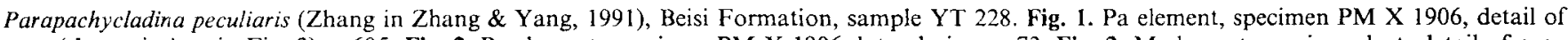

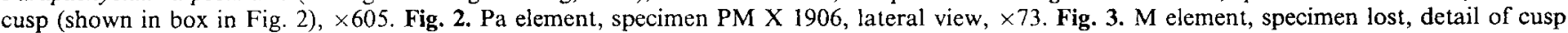

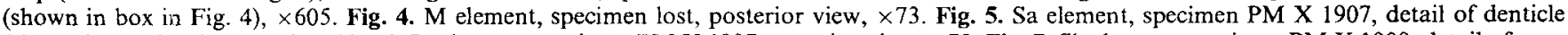

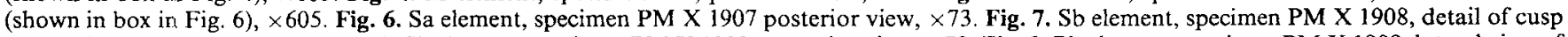

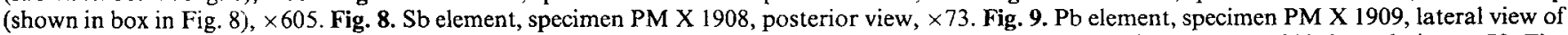

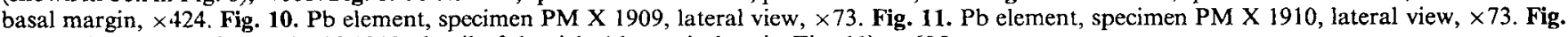
12. $\mathrm{Pb}$ element, specimen PM X 1910, detail of denticle (shown in box in Fig. 11), $\times 605$. 
Otoliths are also commonly used in ageing fish and show comparable 'check marks' on an annual scale. Such structures are, however, continuously grown through the life of the animal and so may not be useful in a detailed comparison with conodont teeth which were at least periodically in use.

Incremental layers in vertebrate enamel (the striae of Retzius) were interpreted by Schour \& Hoffman (1939a, b) as representative of a daily rhythm of secretion. Subsequent studies have led to suggestions that cross-striations perpendicular to the axes of the enamel prism reflect a circadian rhythm, whereas the striae of Retzius, which are oblique lines through the enamel, record an approximate seven-day rhythm (see Dean, 1987; Rozzi, 1994). Growth bands at several spatial scales have been described in mammalian dentine, reflecting days, months, seasons or years (see e.g. Laws, 1952; Carlson, 1990). Phillips et al. (1982) found a high variability in the pattern of incremental lines in the dentine and cementum of living bats and urged caution in using them to determine age; they did, however, conclude that there generally is a loose correlation between the number of lines and age.

The incremental layers of the Parapachycladina enamel could, therefore, represent daily or weekly rhythms rather than monthly or annual cycles. However, conodonts are so distantly related to the other vertebrates studied that intepretations must be equivocal. The more closely related myxinoids do not have biomineralized skeletal elements, but do episodically shed the functional keratinous coverings of their lingual teeth (Krejsa et al., 1990a,b). We can find no record of the frequency patterns of this shedding. Similar problems exist with lampreys, and there are no extant biomineralizing agnathans. Little work has been undertaken on growth patterns in the skeletal hard parts of extinct agnathans. Märss (1992) described rhythmicity in thelodont dermal denticles from the Silurian of the Baltic but offered no specific interpretation.

A few models exist that seek to explain the mode of growth of conodont elements. Krejsa et al. (1990a,b), for example, proposed a homology between the growth of myxinoid teeth and those of conodonts. However, the lingual teeth of the hagfish do not compare with conodont elements in composition or internal histology.

Another model, proposed by Bengston (1976, 1983), suggested that each individual lamella represents a single phase of growth interrupted by eversion of the 'tooth' from the phosphate-secreting epithelial pocket. The tooth was then retracted and another phase of growth began. If this is the case, any broader cycles would represent a longer-period physiological cyclicity imposed upon the animal, possibly by environmental changes. Müller \& Nogami (1972) interpreted variation in lamellar thickness within an individual as a response to seasonal variations in phosphate solubility in sea water. An annual winter pause in secretion would be a possible explanation of the broader interlamellar spaces shown by Parapachycladina; our specimens show three such pauses in their growth history and might possibly have been no more than four years old when the animal died or shed its teeth.

Bengtson's growth model has been questioned on the basis of space problems (Conway Morris, 1980) and is not fully compatible with improved understanding of conodont element function (Purnell \& von Bitter, 1992; Purnell, 1995). It has become clear that this hypothesis is too simplified, and full interpretation of the lamellar structures we describe here probably awaits the development of a more comprehensive growth model. However, we can review alternative possible explanations. These would differ if conodont elements were either (a) shed and replaced, or (b) retained as permanent teeth.

The hypothesis that conodont elements were deciduous, as is common in vertebrates, was first argued by Carls (1977). In this event, replacement teeth would grow quickly and the episodicity recorded by the lamellae would represent short-term cyclicity prior to eruption, possibly daily, weekly, monthly, or combinations of these. There is currently no direct evidence that conodonts repeatedly shed and replaced their teeth; indeed, most evidence suggests an alternative view (Jeppsson, 1976; Purnell, 1994). If, however, shedding has occurred in Parapachycladina, then the presence of comparable sets of lamellae in all elements would indicate discarding of the whole apparatus at one time.

If the elements were grown then erupted as a permanent tooth, the lamellar pattern would be open to the same interpretation; the episodicity could be regarded as daily, weekly or monthly.

A third possibility is that aiternate periods of function and growth occurred, in which the permanent but worn tooth was repaired and enlarged repeatedly during ontogeny. The latter interpretation is essentially an amendment of the original Bengtson (1976, 1983) model, with each lamella interpreted as a single growth stage recording a possible daily increment, during a much larger growth phase. Such phases may be recorded in Parapachycladina by the prominent 'sets' of lamellae.

Size distribution analysis of Silurian ozarkodinid conodont elements carried out by Jeppsson (1976) also indicated three growth cycles in mature specimens. If these cycles were annual, then the age of the mature Silurian ozarkodinid specimens compares closely with that suggested for our Triassic Parapachycladina. The growth/resorption patterns described by Müller \& Nogami $(1971,1972)$ also record up to four complete cycles.

\section{Explanation of Plate 4}

Parapachycladina peculiaris (Zhang in Zhang \& Yang, 1991), Beisi Formation, sample YT 228. Fig. 1. Slightly oblique transverse section through the cusp of Sb element, specimen PM X 1911, exhibiting three sets of growth lamellae (arrowed) with intervening white matter, $\times 302$. Figs $2-4$. Transverse section through $\mathrm{Pb}$ element, specimen PM X 1912, exhibiting at least two sets of growth lamellae, Fig. 2. $\times 212$, Fig. 3. The relationship between the lamellar tissue (left) and the finely crystalline, porous white matter (right), $\times 1028$, Fig. 4. $\times 424$. Fig. 5. Transverse section through $\mathrm{Pb}$ element, specimen PM X 1913, showing the white matter core to the cusp, $\times 302$. Figs 6, 7. Transverse section through Pb element, specimen PM X 1914, at least two sets of lamellae can be discerned, Fig. 6. $\times 484$, Fig. 7. $\times 212$. 


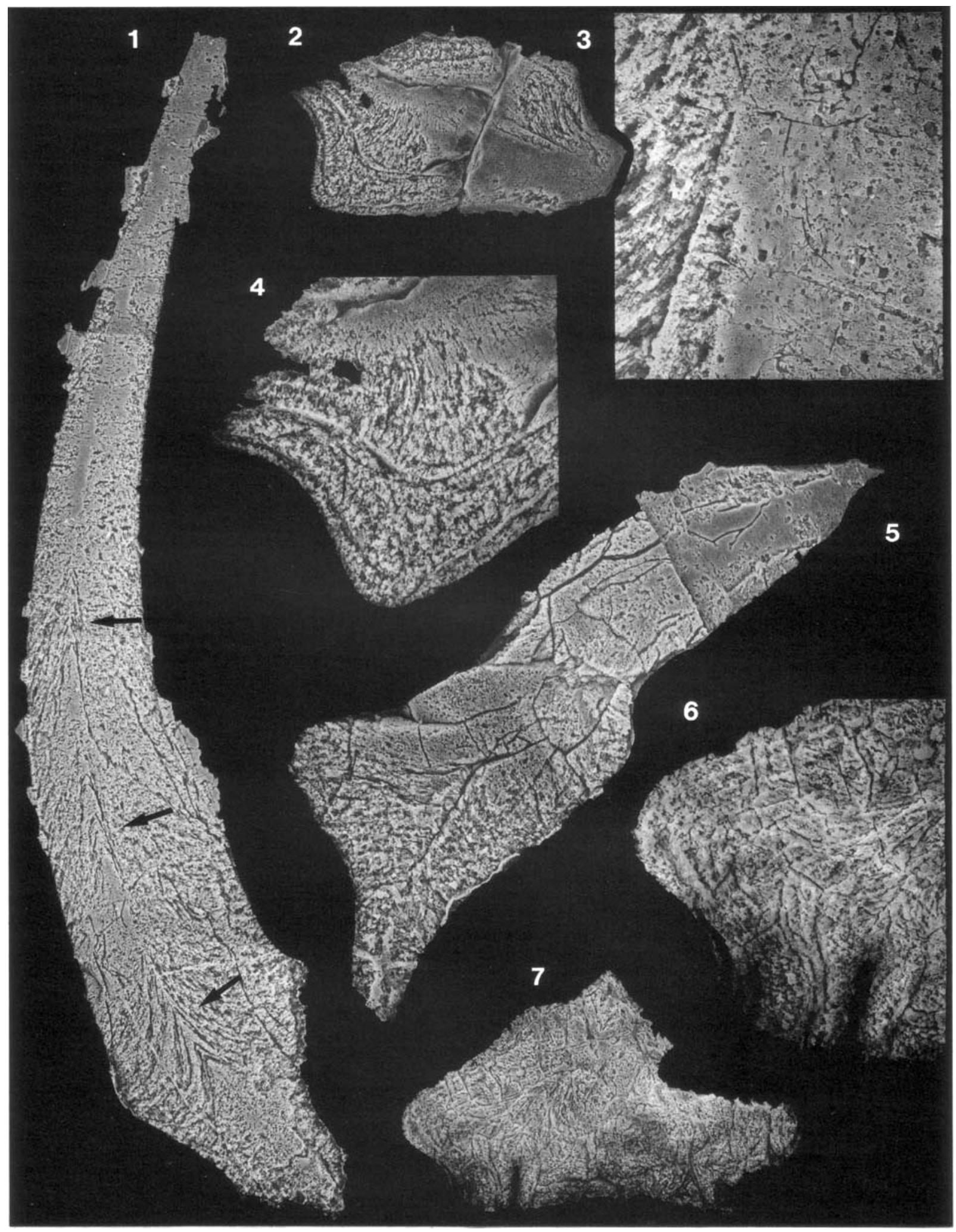

Plate 4 


\section{ACKNOWLEDGEMENTS}

We gratefully acknowledge the award of a Royal Society SinoBritish Fellowship, which allowed Zhang Shunxin to work in Britain for 6 months. M. A. Purnell made valuable comments on an initial version of the text, as did two anonymous referees; $D$. C. Aldridge provided information on fish ageing.

\section{Manuscript received September 1994 Manuscript accepted November 1995}

\section{REFERENCES}

Aldridge, R. J., Briggs, D. E. G., Smith, M. P., Clarkson, E. N. K. \& Clark, N. D. L. 1993. The anatomy of conodonts, Philosophical Transactions of the Royal Society, London B, 340: 405-421.

Bengtson, S. 1976. The structure of some Middle Cambrian conodonts, and the early evolution of structure and function. Lethaia, 9: 185-206.

Bengtson, S. 1983. The early history of the Conodonta. Fossils and Strata, 15: 5-19.

Briggs, D. E. G. 1992. Conodonts: a major extinct group added to the vertebrates. Science, 256: 1285-1286.

Carls, P. 1977. Could conodonts be lost and replaced? Neues Jahrbuch fur Geologie und Palontologie Abhandlungen, 155: 18-64.

Carlson, S. J. 1990. Vertebrate dental structure. In Carter, J. G. (Ed.) Skeletal Biomineralization: Patterns, Processes and Evolutionary Trends. Volume 1, 531-556. Van Nostrand Reinhold, New York.

Clark, D. L. 1972. Early Permian crisis and its bearing on PermoTriassic conodont taxonomy. Geologica et Palaeontologica, SB1: 147158.

Conway Morris, S. 1980. Conodont function: falacies of the tooth model. Lethaia, 13: 107-108.

Dean, M. C. 1987. Growth layers and incremental markings in hard tissues; a review of the literature and some preliminary observations about enamel structure in Paranthropus boisei. Journal of Human Evolution, 16: 157-172.

Gabbott, S. E., Aldridge, R. J. \& Theron, J. N. 1995. A giant conodont with preserved muscle tissue from the Upper Ordovician of South Africa. Nature, 374: 800-804.

Hartley, P. H. T. 1947. The Coarse Fishes of Britain. Freshwater Biological Association, Scientific Publication No. 12, 40 pp.

Janvier, P. 1995. Conodonts join the club. Nature, 374: 761-762.

Jeppsson, L. 1976. Autecology of late Silurian conodonts. In Barnes, C. R. (Ed.), Conodont Paleoecology. Geological Association of Canada Special Paper 15, 105-118.

Kresja, R. J., Bringas, P. Jr \& Slavkin, H. C. 1990a. The cyclostome model: an interpretation of conodont element structure and function based on cyclostome tooth morphology, function, and life history. Courier Forschungsinstitut Senckenberg, 118: 473-492.

Krejsa, R. J., Bringas, P. Jr \& Slavkin, H. C. 1990b. A neontological intepretation of conodont elements based on agnathan cyclostome tooth structure, function and development. Lethaia, 23: 359-378.

Laws, 1952. A new method of age determination in mammals. Nature, 169: $972-973$.

Lindström, M. \& Ziegler, W. 1981. Surface micro-ornamentation and observations on internal composition. In Robison, R. A. (Ed.), Treatise on Invertebrate Paleontology, Part $W$, Supplement 2, Conodonta, W41-W52. Geological Society of America and University of Kansas Press, Lawrence, Kansas.
Märss, T. 1992. The structure of growth layers of Silurian fish scales as a potential evidence of the environmental changes. In Mark-Kurik, E. (Ed.) Fossil Fishes as Living Animals, 41-48. Academy of Sciences of Estonia, Institute of Geology, Tallinn.

Müller, K. J. 1956. Triassic conodonts from Nevada. Journal of Paleontology, 30: 818-830, pls 95-96.

Müller, K. J. \& Nogami, Y. 1971. Über den Feinbau der Conodonten. Memoirs of the Faculty of Science, Kyoto University, Series Geology and Mineralogy, 38: 1-88, 22 pls.

Müller, K. J. \& Nogami, Y. 1972. Growth and function of conodonts. International Geological Congress, 24th Session, Montreal, 20-27.

Pander, C. H. 1856. Monographie der fossilen Fische des silurischen Systems der russisch-baltischen Gouvernrments. Akademie der Wissenschaften, St. Petersburg, 1-91.

Panella, G. 1971. Fish otoliths: daily growth layers and periodical patterns. Science, 173: 1124-1127.

Philips, C. J., Steinberg, B. \& Kunz, T. H. 1982. Dentin, cementum, and age determination in bats: a critical evaluation. Journal of Mammalogy, 63: 197-207.

Purnell, M. A. 1994. Skeletal ontogeny and feeding mechanisms in conodonts. Lethaia, 27: 129-138.

Purnell, M. A. 1995. Microwear on conodont elements and macrophagy in the first vertebrates. Nature, 374: 798-800.

Purnell, M. A. \& von Bitter, P. H. 1992. Blade-shaped conodont elements functioned as cutting teeth. Nature, 359: 629-630.

Rozzi, F. V. R. 1994. Enamel growth markers in hominid dentition. Microscopy and analysis, 42: 37-39.

Sansom, I. J., Smith, M. P., Armstrong, H. A. \& Smith, M. M. 1992. Presence of the earliest vertebrate hard tissues in conodonts. Science, 256: 1308-1311.

Schour, I. \& Hoffman, M. M. 1939a. Studies in tooth development. I. The 16 microns calcification rhythm in the enamel and dentin from fish to man. Journal of Dental Research, 18: 91-102.

Schour, I. \& Hoffman, M. M. 1939b. Studies in tooth development. II. The rate of apposition of enamel and dentin in man and other mammals. Journal of Dental Research, 18: 161-175.

Solien, M. A. 1979. Conodont biostratigraphy of the Lower Triassic Thaynes Formation, Utah. Journal of Paleontology, 53: 276-306, 3 pls,

Staesche, U. 1964. Conodonten aus dem Skyth von SŸdtirol. Neues Jahrbuch für Geologie und Paläontologie Abhandlungen, 119: 247-306, pls 28-32.

Sweet, W. C. 1981. Family Ellisoniidae Clark, 1972. In Robison, R. A. (Ed.), Treatise on Invertebrate Paleontology, Part W, Supplement 2, Conodonta, W152-W154. Geological Society of America and University of Kansas Press, Lawrence, Kansas.

Sweet, W. C. 1988. The Conodonta: Morphology, Taxonomy, Paleoecology, and Evolutionary History of a Long-Extinct Animal Phylum. Oxford University Press, New York.

Tesch, F. W. 1971. Age and growth. In Ricker, W. E. (Ed.) Methods for Assessment of Fish Production in Fresh Waters, 2nd edn, 98-130. International Biological Programme Handbook No, 3, Blackwell Scientific Publications, Oxford.

Zhang Shunxin. 1990. On the Lower Triassic conodont sequence of Western Guangxi [In Chinese with English abstract]. Geoscience, 4: 115,2 pls.

Zhang Shunxin \& Yang Zunyi. 1991. On multielement taxonomy of the Early Triassic conodonts. Stratigraphy and Paleontology of China, 1: $17-47,4$ pls.

Zhang Shunxin \& Yang Zunyi. 1993. Application of R-mode cluster analysis to multielement taxonomy of Early Triassic conodonts. Journal of China University of Geosciences, 4: 14-22, 5 pls. 